\title{
UN POEMA ISLANDÉS SOBRE DON QUIJOTE
}

Con ocasión de la lectura de una tesis doctoral en febrero de 1992 (Aitor Yraola, La repercusión de la guerra civil española en Islandia, Universidad Autónoma de Madrid) cayó en mis manos la versión original islandesa de un poema titulado "Don Quijote». Se trata de una interpretación, en clave cervantina, del drama de la guerra civil española.

Su autor, Steinn Steinarr (1908-1958), es probablemente el poeta islandés más original de este siglo. Fue uno de los iniciadores del modernismo en Islandia, gran conocedor de la obra de los suecos Lindegren y Martison, de los finlandeses Diktonius y Södergran, de los noruegos Bull y Nygard, conocedor también del surrealismo francés, particularmente de Eluard, y de la obra de García Lorca y, sobre todo, de Ezra Pound.

Stein Steinarr, nacido en el medio rural, se trasladó a Reykjavík, donde llevó una vida de privaciones y dificultades, ya que sus medios no le permitían seguir estudios y su defecto físico (un brazo inútil -otra concomitancia cervantina), no le permitía realizar trabajos manuales. Más tarde, cuando le llegó el merecido reconocimiento de sus paisanos, recordaría aquellos años difíciles, en los que malvivía del periodismo, en dos líneas que se hicieron famosas:

«Malvestido y hambriento escribí para El Pueblo, pero a El Pueblo y a mi nos cubrieron de oprobios".

Su primer libro de poemas (La hoguera roja, 1934), escrito en medio de la situación social reinante en Islandia -el paro y la crisis de los años 30- recoge su simpatía por el comunismo y sus versos son un canto a todos aquellos que luchan 
contra un opresor. Otra obra importante es El tiempo y el agua (1948).

El poema me atrajo en seguida, al igual que otros suyos que ya conocía, y me sugirió la idea de redactar esta nota incluyendo el original islandés y mi traducción literal y directa.

\section{JOSÉ ANTONIO FERNÁNDEZ ROMERO}

\section{«DON QUIJOTE}

Einn dag mun Don Quijote söøla sinn hvita hest og segja við Sancho Panza:

Pessi auðugi maður, sem myroir og brennir, og járnuðum hœl treður jöro hinna snauðu, hann skal falla!

Pað er hann, sem er óvinur minn.

Pað̃ var hann, sem villti oss sýn, út á veglausar auðnir, og vort heilaga strío gerði að harmprungnum skopleik meðan Dulcina fagra var ein af ambáttum hans.

Pað var hann, lað var hann! Og vér pekktum hann ekki."

Steinn Steinarr:

\section{DON QUIJOTE}

Un día Don Quijote montará su caballo y dirá a Sancho Panza:

Ese hombre acaudalado que asesina y abrasa, 
hollando con sus botas la tierra de los pobres, debe caer, pues él es mi enemigo.

Fue él quien nos sedujo por desiertos sin sendas y nuestra guerra santa convirtió en burla trágica y a Dulcinea la bella sometió a servidumbre.

¡Fue él! ¡Fue él!

Y no le conocimos. 